\title{
Treatment of the lung injury of drowning: a systematic review
}

\author{
Ogilvie Thom ${ }^{1,2^{*}} \mathbb{D}$, Kym Roberts $^{1,2}$, Susan Devine ${ }^{1}$, Peter A. Leggat ${ }^{1,3}$ and Richard C. Franklin ${ }^{1,4}$
}

\begin{abstract}
Background: Drowning is a cause of significant global mortality. The mechanism of injury involves inhalation of water, lung injury and hypoxia. This systematic review addressed the following question: In drowning patients with lung injury, what is the evidence from primary studies regarding treatment strategies and subsequent patient outcomes?
\end{abstract}

Methods: The search strategy utilised PRISMA guidelines. Databases searched were MEDLINE, EMBASE, CINAHL, Web of Science and SCOPUS. There were no restrictions on publication date or age of participants. Quality of evidence was evaluated using GRADE methodology.

Results: Forty-one papers were included. The quality of evidence was very low. Seventeen papers addressed the lung injury of drowning in their research question and 24 had less specific research questions, however included relevant outcome data. There were 21 studies regarding extra-corporeal life support, 14 papers covering the theme of ventilation strategies, 14 addressed antibiotic use, seven papers addressed steroid use and five studies investigating diuretic use. There were no clinical trials. One retrospective comparison of therapeutic strategies was found. There was insufficient evidence to make recommendations as to best practice when supplemental oxygen alone is insufficient. Mechanical ventilation is associated with barotrauma in drowning patients, but the evidence predates the practice of lung protective ventilation. There was insufficient evidence to make recommendations regarding adjuvant therapies.

Conclusions: Treating the lung injury of drowning has a limited evidentiary basis. There is an urgent need for comparative studies of therapeutic strategies in drowning.

Keywords: Drowning, Review, Ventilation, Non-invasive ventilation, Lung injury

\section{Background}

Drowning is a major cause of preventable death and morbidity worldwide. There are over 295,000 unintentional drowning deaths (excluding boating) per year [1, 2]. Ninety percent of these deaths occur in middle- and low-income countries, and half the fatalities are aged less than 25 years [1]. Despite the modern medical literature on drowning reaching back at least as far as The Lancet in 1878 [3], there have only recently been efforts

*Correspondence: Ogilvie.Thom@my.jcu.edu.au

${ }^{1}$ College of Public Health, Medical and Veterinary Sciences, James Cook University,Townsville, QLD, Australia

Full list of author information is available at the end of the article to standardise definitions [4] and data collection [5] for drowning research. The majority of the published studies focus on three themes-preventative strategies such as secure pool fencing, high-risk groups such as children and factors determining clinical outcome, especially duration of immersion [2, 6-8].

The mechanism of drowning involves aspiration of water into the lung which damages surfactant, disrupts the alveolar capillary membrane and leads to the development of alveolar oedema, resulting in a local acute respiratory distress syndrome (ARDS)-like syndrome [6]. A high proportion of drowning patients are hypoxic and have a $\mathrm{PaO}_{2} / \mathrm{FiO}_{2}$ ratio $<300 \mathrm{~mm} \mathrm{Hg}[9,10]$. Treating this original author(s) and the source, provide a link to the Creative Commons licence, and indicate if changes were made. The images or other third party material in this article are included in the article's Creative Commons licence, unless indicated otherwise in a credit line to the material. If material is not included in the article's Creative Commons licence and your intended use is not permitted by statutory regulation or exceeds the permitted use, you will need to obtain permission directly from the copyright holder. To view a copy of this licence, visit http://creativecommons.org/licenses/by/4.0/. The Creative Commons Public Domain Dedication waiver (http://creativeco mmons.org/publicdomain/zero/1.0/) applies to the data made available in this article, unless otherwise stated in a credit line to the data. 
lung injury and reversing the hypoxia are the cornerstone of the management of drowning [7].

However, current ventilation guidelines for drowning patients are adapted from ARDS $[7,11]$ and as such may not reflect the needs of the drowned patient. The aim of this paper is to review the existing evidence to guide the clinician in the treatment of the lung injury and respiratory distress associated with drowning.

\section{Methods}

\section{Research question}

The patient, intervention, comparison and outcome (PICO) question being addressed is: In drowning patients with lung injury, what is the evidence from primary studies regarding comparisons of treatment strategies and subsequent patient outcomes?

This is a systematic review using the Preferred Reporting Items for Systematic Reviews and Meta-Analyses (PRISMA) [12] to explore the treatment of drowning.

\section{Protocol}

The protocol for this review is available on Prospero; "Treating the respiratory impairment of drowning: A systematic review" (CRD420203896).

\section{Inclusion criteria}

This review included papers with human participants, who had drowned, and that included outcome data for interventions designed to treat the lung injuries associated with drowning. Outcomes of interest were mortality, escalation of ventilation strategy, duration of ventilation, ARDS, pneumonia and barotrauma. There was no restriction on publication date or age of participants. Systematic reviews and meta-analyses, where available, were included if they reported primary data outcome of interest.

\section{Exclusion criteria}

Papers in a language other than English and animal studies were excluded. Letters, editorials, reviews and case reports were also excluded. Studies contributing data to included systematic reviews or meta-analyses were not individually included in this review.

\section{Search strategy}

The PRISMA methodology for searching the literature was utilised to ensure a systematic approach was taken [12]. The search strategy was constructed for use on Medline and adapted for use on EMBASE, CINAHL, Web of Science and SCOPUS. Searches were conducted on 15 January 2021, with no date limitations. The full search strategy is detailed in Additional file 1 and included $\mathrm{MeSH}$ terms for the environment such "critical care" and "emergency department", the condition "drowning" and "near drowning" and the intervention such as "noninvasive ventilation", "mechanical ventilation" and "ECLS treatment". Reference lists of included articles and relevant reviews were also searched. Screening of the search results by title, abstract and then full text was conducted by two authors (OT and KR) for inclusion. Where agreement was not achieved, these were referred to a third author (RF). Where outcome data were unclear, attempts were made to contact the corresponding author for clarification. The results of the search strategy are presented in Fig. 1.

\section{Appraisal of selected studies}

Data were independently extracted from selected articles using a standardised form by two authors (OT and KR). All papers were assessed for the quality of the evidence utilising Grading of Recommendations Assessment, Development and Evaluation (GRADE) methodology [13]. Observational studies were defined prior to assessment as having a low quality of evidence [14]. The GRADE evidence profile for included studies is included in Additional file 2.

\section{Results}

There were 41 studies which met the inclusion criteria. The summary table of included studies is detailed in Additional file 3. They included data on patients from 20 countries with the USA [15-27] and France [28-31] most frequently represented. Patient data were reported on 1973 patients. Patient demographics were incomplete with regards to gender in eleven papers $[19,20,25-27$, 31-35]. Data presented included 1093 (55.4\%) males and $545(27.6 \%)$ females and were similarly incomplete with regards to age groups in seven papers $[10,16,31$, $32,34,36,37]$, with a minimum of $675(34.5 \%)$ children included. Studies were predominately $(30 / 41,73.2 \%)$ from intensive (critical) care units [10, 16, 20-31, 34-51], $6 / 41$ (14.6\%) from inpatient units [9, 15, 17, 18, 41, 52] and five $(12.2 \%)$ studies were based in the Emergency Department [19, 32, 33, 53, 54]. Three studies utilised the Utstein Style for drowning [28, 29, 44].

A total of 17 papers were identified where the lung injury of drowning was the focus of the research question $[9,10,20-22,28-31,36,37,39,43,44,47,50,51$, 53]. Twenty-four papers where the lung injury of drowning was not the focus of the research question that nevertheless included information relevant to the review were included [15-19, 23-27, 32-35, 37, 38, 40, 41, 45, $46,48,49,52,54]$. All were case series other than one retrospective cohort study [29] and two multicentre registry studies $[21,26]$. The GRADE level was universally $(41 / 41$, $100 \%$ ) rated as very low. 


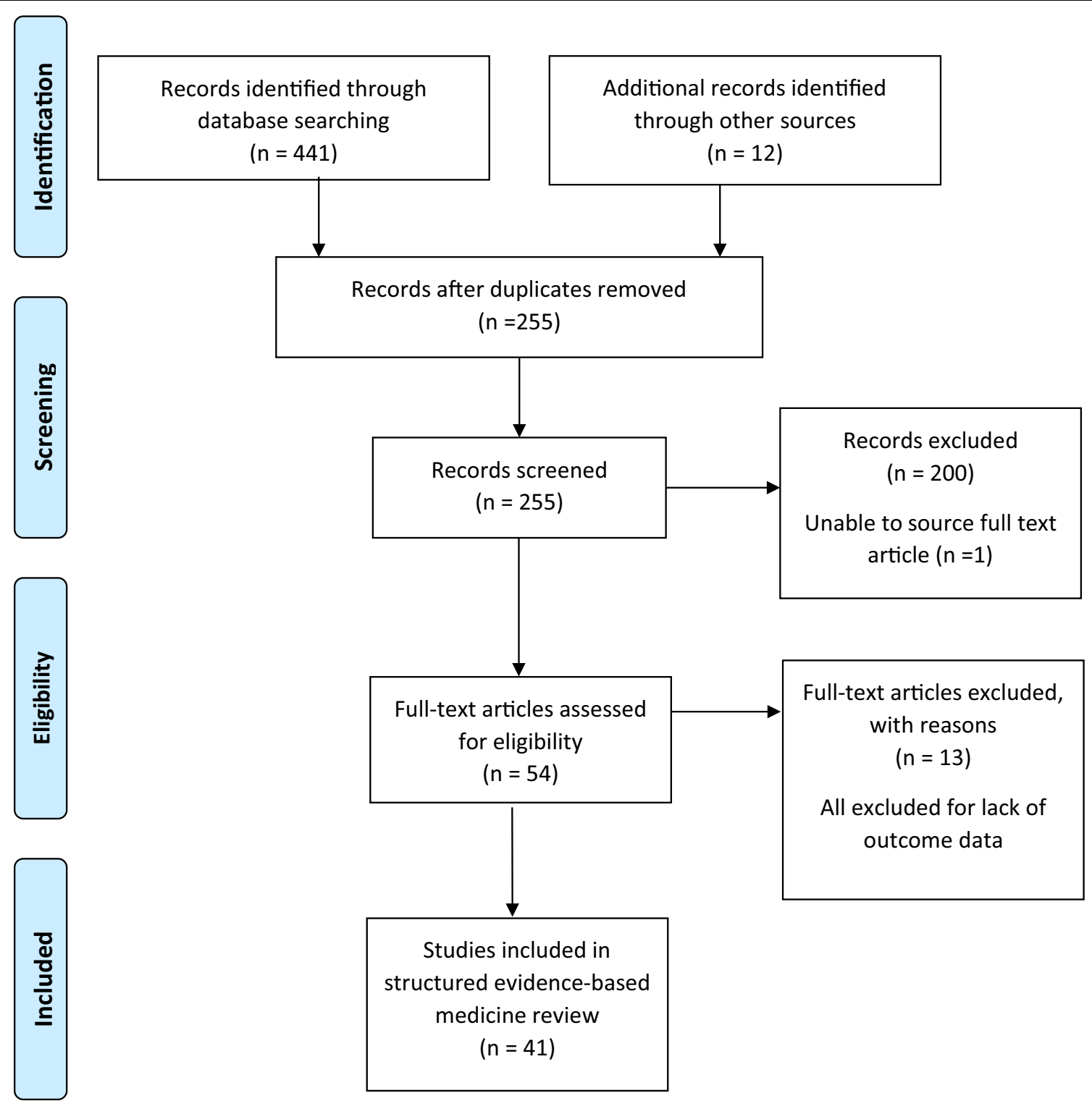

Fig. 1 PRISMA flowchart

Mortality was reported in all papers. There was considerable overlap amongst treatment groups and reported outcomes frequently included multiple treatment groups. Insufficient studies were free of these issues to allow meta-analysis. Extracorporeal life support (ECLS) was the most common theme (21 articles) [20, 21, 23-27, $31,34,35,37,43-51]$ followed by ventilatory strategies (14 articles) [9, 10, 15, 17, 19, 28, 29, 32, 38-41, 53, 54], the use of prophylactic antibiotics to prevent aspiration or early onset post-drowning pneumonia (14 articles) $[9,10,16-18,30,33,36,38-41]$, the use of corticosteroids (7 articles) $[16,18,33,36,40,41,52]$ and the use of diuretics (5 articles) [9, 18, 40, 41, 52]. A summary of the aims, the population studied, the study setting, treatment strategies, methodology, results and GRADE level of the selected studies is included in Additional file 3.

\section{Extra-corporeal life support}

The ECLS studies fall into two categories. Six studies [21, 25-27, 37, 47] report on ECLS in drowning with a survival rate of 156/290 (53.7\%). Fifteen studies reported on ECLS for drowning associated with accidental hypothermia $[20,22-24,31,34,35,43-46,48-51]$. The survival rate was $35 / 120(29.2 \%)$. Overall, the survival rate for ECLS in drowning is 191/410 (46.6\%) (Table 1). 
Burke et al. published data on 247 drowning patients on the Extracorporeal Life Support Organization international database, covering a 30-year period. They reported good outcomes in patients who had not experienced cardiac arrest where ECLS was initiated for refractory respiratory failure $(60 / 84,71.4 \%$ survival). In post-cardiac arrest patients, where ECLS was initiated following ROSC, survival was still high but lower (49/86, 57.0\%). Survival in drowning patients was lowest when ECLS was initiated during cardiac arrest (18/77, 23.4\%).

Table 1 ECLS and drowning

\begin{tabular}{|c|c|c|c|}
\hline Study & Outcome measured & Outcome & Confounders \\
\hline \multicolumn{4}{|l|}{ Drowning } \\
\hline Steiner et al. [25] & Mortality & 3/8 (37.5\%) survived & $\begin{array}{l}\text { No validated assessment tool used for neurological } \\
\text { outcome }\end{array}$ \\
\hline Weber et al. [27] & $\begin{array}{l}\text { Mortality } \\
\text { Neurological outcome }\end{array}$ & $1 / 4(25.0 \%)$ survived & $\begin{array}{l}\text { No validated assessment tool used for neurological } \\
\text { outcome }\end{array}$ \\
\hline Kim et al. [47] & $\begin{array}{l}\text { Mortality } \\
\text { Neurological outcome }\end{array}$ & $\begin{array}{l}\text { 8/9 (88.9\%) rapidly worsening ARDS } \\
7 / 9(77.8 \%) \text { survived } \\
7 / 9(77.8 \%) \text { good neurological outcome }\end{array}$ & $\begin{array}{l}\text { No validated assessment tool used for neurological } \\
\text { outcome }\end{array}$ \\
\hline Burke et al. [21] & Mortality & $\begin{array}{l}\text { 60/84 (71.2\%) survived (no cardiac arrest } \\
\text { prior to ECLS) } \\
49 / 86(56.9 \%) \text { survived (cardiac arrest fol- } \\
\text { lowed by ROSC prior to ECLS) } \\
18 / 77(23.3 \%) \text { survived (ECPR) }\end{array}$ & No neurologic outcome reported \\
\hline Watson et al. [26] & Mortality & $3 / 4(75 \%)$ survival & No neurologic outcome reported \\
\hline Lee et al. [37] & Mortality & $15 / 18(83.3 \%)$ & No neurologic outcome reported \\
\hline \multicolumn{4}{|l|}{ Drowning + Hypothermia } \\
\hline Saltiel et al. [22] & $\begin{array}{l}\text { Mortality } \\
\text { Neurological outcome }\end{array}$ & 2/3 (66.6\%) survived, 1/3 (33.3\%) GNO & $\begin{array}{l}\text { No validated assessment tool used for neurological } \\
\text { outcome }\end{array}$ \\
\hline Walpoth et al. [34] & $\begin{array}{l}\text { Mortality } \\
\text { Neurological outcome }\end{array}$ & $0 / 2(0.0 \%)$ survived & $\begin{array}{l}\text { No validated assessment tool used for neurological } \\
\text { outcome }\end{array}$ \\
\hline Mair et al. [48] & $\begin{array}{l}\text { Mortality } \\
\text { Neurological outcome }\end{array}$ & 1/7 (14.3\%) survived & $\begin{array}{l}\text { No validated assessment tool used for neurological } \\
\text { outcome }\end{array}$ \\
\hline Farstad et al. [45] & Mortality & 1/14 (7\%) survived & Neurological data presented as group results \\
\hline Wollenek et al. [51] & $\begin{array}{l}\text { Mortality } \\
\text { Neurological outcome }\end{array}$ & $\begin{array}{l}\text { 2/3 (66.6\%) survived } \\
1 / 3(33.3 \%) \text { poor neurological outcome } \\
1 / 3(33.3 \%) \text { good neurological outcome }\end{array}$ & $\begin{array}{l}\text { No validated assessment tool used for neurological } \\
\text { outcome }\end{array}$ \\
\hline Eich et al. [44] & $\begin{array}{l}\text { Mortality } \\
\text { Neurological outcome } \\
\text { USFD }\end{array}$ & $\begin{array}{l}5 / 12(42 \%) \text { survived } \\
2 / 12(17 \%) \text { full recovery (PCPC 1) } \\
3 / 12(25 \%)(\text { PCPC 5) }\end{array}$ & Paediatric cerebral performance category \\
\hline Scaife et al. [23] & $\begin{array}{l}\text { Mortality } \\
\text { Neurological outcome }\end{array}$ & $1 / 5$ (20\%) survived & $\begin{array}{l}\text { No validated assessment tool used for neurological } \\
\text { outcome }\end{array}$ \\
\hline Coskun et al. [43] & $\begin{array}{l}\text { Mortality } \\
\text { Neurological outcome }\end{array}$ & $\begin{array}{l}\text { 5/13 (38\%) survived } \\
3 / 13(23 \%) \text { severe neurological deficit }\end{array}$ & $\begin{array}{l}\text { No validated assessment tool used for neurological } \\
\text { outcome }\end{array}$ \\
\hline Suominen et al. [49] & $\begin{array}{l}\text { Mortality } \\
\text { Neurological outcome }\end{array}$ & 1/9 (11\%) survived & $\begin{array}{l}\text { No validated assessment tool used for neurological } \\
\text { outcome }\end{array}$ \\
\hline Wanscher et al. [35] & $\begin{array}{l}\text { Mortality } \\
\text { Neurological outcome }\end{array}$ & $\begin{array}{l}\text { 7/7 (100\%) survived } \\
\text { GOSE ranged from 3-7 }\end{array}$ & Group results given for neurological outcome \\
\hline Skarda et al. [24] & $\begin{array}{l}\text { Mortality } \\
\text { Neurological outcome }\end{array}$ & 0/7 (0\%) survived & \\
\hline Champigneulle et al. [31] & $\begin{array}{l}\text { Mortality } \\
\text { Neurological outcome } \\
\text { USFD }\end{array}$ & $\begin{array}{l}\text { 2/20 (10\%) survived } \\
1 \text { good neurological outcome (CPC 1) } \\
1 \text { severe cerebral disability (CPC 3) }\end{array}$ & Validated neurological outcome score used \\
\hline Weuster et al. [50] & $\begin{array}{l}\text { Mortality } \\
\text { Neurological outcome } \\
\text { Drowning definition }\end{array}$ & $\begin{array}{l}\text { 2/9 (22\%) survived } \\
\text { 2/9 GNO }\end{array}$ & $\begin{array}{l}\text { No validated assessment tool used for neurological } \\
\text { outcome }\end{array}$ \\
\hline Khorsandi et al. [46] & Mortality & 3/4 survived & No neurologic outcome reported \\
\hline Bauman et al. [20] & $\begin{array}{l}\text { Mortality } \\
\text { Neurological outcome }\end{array}$ & $3 / 5$ survived & $\begin{array}{l}\text { No validated assessment tool used for neurological } \\
\text { outcome }\end{array}$ \\
\hline
\end{tabular}

ECLS, Extra-corporeal life support; GNO, good neurological outcome; ROSC, return of spontaneous circulation; ECPR, ECLS-assisted cardio-pulmonary resuscitation; PCPC, paediatric cerebral performance category; GOSE, Glasgow Outcome Scale Extended; USFD, Utstein Style for Drowning; CPC, cerebral performance category 


\section{Mechanical ventilation}

Mechanical ventilation (MV) is often used when supplemental oxygen alone is insufficient $[15,17,19,29,39,41$, 54]. Other indications include decreased conscious state $[28,52]$ or cardiac arrest $[15,32,39,41,54]$. Complications of MV include the development of pneumonia [36] and barotrauma $[15,17,19]$. The reported frequency of barotrauma is high, with an incidence of $75 \%, 12 \%$ and $10 \%[15,17,19]$, respectively. Since these earlier papers, MV strategies have evolved into the practice termed lung protective ventilation (LPV), which decreases ventilatorassociated lung injury [55], and this practice is currently advocated for the treatment of drowning patients $[7,11]$. Michelet et al. reports using LPV in 30 drowning patients with no barotrauma reported [28]. Unfortunately, barotrauma was not identified as an outcome of interest in the paper. Duration of mechanical ventilation has not changed greatly. A study of 25 patients reported a mean duration of MV of 4.3 days in 1982 [17], but data from two recent papers [28, 29] demonstrate a mean (SD) duration of $6( \pm 12)$ days $(n=70)$.

Other outcomes reported for MV typically include survival and neurological status [15, 32, 41]. Given the coexistence of hypoxic encephalopathy in many of these patients [38], it is impossible to comment on the success or otherwise of mechanical ventilation in aiding survival (Table 2).

\section{Non-invasive ventilation}

There were four papers [28, 29, 39, 40] reporting on noninvasive ventilation (NIV) with the majority $(3 / 4,75 \%)$ published since 2017 [28, 29, 39] (Table 3). The earliest report of successful use of NIV dates from 1982, where eleven patients were successfully treated with continuous positive airway pressure (CPAP) [40]. Recently, three larger studies all from France or its overseas territories have been published [28, 29, 39]. Cerland et al. report use of NIV in 28 patients with acute respiratory failure [39]. Outcomes are not explicitly reported, but all deaths $(n=45)$ in their cohort of 144 had experienced prehospital cardiac arrest [39]. The other two series of NIV patients are from the same group located in the south of France [28, 29]. Their 2017 paper describes a population of 25 patients who received NIV from emergency medical services (EMS) and additional 23 patients put on NIV in the ED after arrival at hospital. Four of the patients put on NIV by EMS subsequently received MV (three because of worsening respiratory failure), and all patients survived [28]. Patients receiving NIV were different from those receiving $\mathrm{MV}$. They were more alert (Glasgow Coma Score $12 \pm 3 \mathrm{NIV}$ vs $7 \pm 2 \mathrm{MV}, \mathrm{P}<0.05)$ and were not as critically ill with lower Simplified Acute Physiology
Scores (28 \pm 8 vs $50 \pm 19)$ and Sequential Organ Failure Assessment scores $(2.4 \pm 2$ vs $6.5 \pm 4)$ [28]. The authors noted a similar rate of improvement in oxygenation between NIV and MV after the first six hours [28]. The second paper retrospectively compared 38 matched pairs $(n=76)$ for fresh versus seawater drowning [29]. Thirteen patients received NIV and 40 patients MV. There were no reported failures of NIV [29]. The mean duration of treatment with NIV was $1.4( \pm 2.4)$ days when the results are combined from both papers $[28,29]$ (Table 3).

\section{Hi-flow nasal prongs}

There was a single article reporting on the use of HFNP [53]. Fifty-seven patients were treated with HFNP, and 12 were converted to MV for worsening ARDS with two patients ultimately requiring ECLS. There were two deaths in the series [53].

\section{Prophylactic antibiotics}

Prophylactic antibiotics were used in 562 (28.5\%) patients from 14 studies. Outcome data were only available on 311 patients from seven studies [9, 16, 33, 38, $41,47,52$ ]. The mortality rate was $23 / 311$ (7.4\%). A single study [16] reported mortality in the patients that did not receive antibiotics $(2 / 36,5.6 \%)$. Two studies reported no improvement from the use of prophylactic antibiotics without including outcome data $[18,36]$ (Table 4).

\section{Prophylactic steroids}

The outcomes reported from seven papers for prophylactic steroids showed no benefit $[16,18,33,36,40,41$, 52]. Overall, 264 patients received prophylactic steroids and $31(11.7 \%)$ died. Ninety-one patients were reported as not being treated with prophylactic steroids and two died (2.2\%). One paper reported an increased hospital length of stay (LOS) in patients who received steroids but did not require mechanical ventilation compared with those not receiving steroids (3.2 vs 1.7 days, supporting data not presented) [41]. A second paper described performing regression analysis to measure the effect of steroids [36] and concluded that there was no effect, but no data supporting this were included [36].

\section{Prophylactic diuretics}

Prophylactic use of diuretics has been reported as having no clinical benefit $[18,40,41]$. However, pre-hospital use of forced diuresis with frusemide by EMS is described in a series of 69 drowning patients from the Dead Sea [52]. There were no fatalities in this study [52]. Similar results are reported in a series of 43 patients from Greece, where only two patients required escalation of therapy secondary to respiratory compromise [9]. 
Table 2 Outcomes of mechanical ventilation in drowning

\begin{tabular}{|c|c|c|c|}
\hline Study & Outcome measured & Outcome & Confounders \\
\hline Fandell et al. [15] & $\begin{array}{l}\text { Mortality } \\
\text { Barotrauma }\end{array}$ & $\begin{array}{l}\text { 12/34 (35\%) MV } \\
\text { 6/12 (50\%) died } \\
\text { 9/12 (75\%) pneumothorax, 8/12(66\%) pneu- } \\
\text { momediastinum }\end{array}$ & Not controlled for other interventions \\
\hline Petersen [19] & $\begin{array}{l}\text { Mortality } \\
\text { Pneumonia } \\
\text { ARDS } \\
\text { Barotrauma }\end{array}$ & $\begin{array}{l}\text { 7/72 (10\%) died } \\
10 / 72(14 \%) \text { barotrauma (all MV) } \\
\text { 29/72 (40\%) pneumonia } \\
6 / 72(9 \%) \text { ARDS }\end{array}$ & $\begin{array}{l}\text { Unclear number of MV patients; outcomes not group } \\
\text { specific }\end{array}$ \\
\hline Corbin [41] & Mortality & 3/8 (38\%) died & Not controlled for other interventions \\
\hline Oakes et al. [17] & $\begin{array}{l}\text { Mortality Barotrauma } \\
\text { Pneumonia }\end{array}$ & $\begin{array}{l}\text { 25/40 (63\%) MV } \\
3 / 25(12 \%) \text { barotrauma } \\
16 / 40(40 \%) \text { pneumonia } \\
10 / 40(25 \%) \text { died }\end{array}$ & $\begin{array}{l}\text { Not controlled for other interventions; outcomes not } \\
\text { group specific }\end{array}$ \\
\hline van Berkel et al. [36] & $\begin{array}{l}\text { Mortality } \\
\text { Pneumonia }\end{array}$ & $\begin{array}{l}\text { 25/102 (25\%) MV } \\
\text { 11/25 (52\%) pneumonia (RR 17.3, P<0.001) } \\
6 / 25(25 \%) \text { died }\end{array}$ & Not controlled for other interventions \\
\hline Lee $[10]$ & Pneumonia & $\begin{array}{l}\text { 8/17 (47.1\%) MV } \\
0 / 17(0.0 \%) \text { pneumonia }\end{array}$ & $\begin{array}{l}\text { Not controlled for other interventions; outcomes not } \\
\text { group specific }\end{array}$ \\
\hline al-Talafieh et al. [32] & $\begin{array}{l}\text { Mortality } \\
\text { Pneumonia } \\
\text { Barotrauma }\end{array}$ & $\begin{array}{l}\text { 14/34 MV } \\
5 / 34(15 \%) \text { died } \\
6 / 34(18 \%) \text { pneumonia } \\
1 \text { PTX }\end{array}$ & Outcomes not group specific \\
\hline Saidel-Odes et al. [52] & $\begin{array}{l}\text { Mortality } \\
\text { Pneumonia } \\
\text { ARDS }\end{array}$ & $\begin{array}{l}\text { 11/69 (16\%) MV patients } \\
26 / 69(38 \%) \text { pneumonia } \\
3 / 69(4 \%) \text { ARDS } \\
\text { No deaths }\end{array}$ & $\begin{array}{l}\text { Not controlled for other interventions; outcomes not } \\
\text { group specific }\end{array}$ \\
\hline Ballesteros et al. [38] & Mortality & $\begin{array}{l}21 / 43(49 \%) \mathrm{MV} \\
15 / 43(35 \%) \text { died }\end{array}$ & $\begin{array}{l}\text { Not controlled for other interventions; outcomes not } \\
\text { group specific }\end{array}$ \\
\hline Kotsiou et al. [54] & $\begin{array}{l}\text { Mortality } \\
\text { ARDS }\end{array}$ & $\begin{array}{l}8 / 20(40 \%) \mathrm{MV} \\
0 \text { deaths } \\
8 / 20(40 \%) \mathrm{mod} / \text { severe ARDS }\end{array}$ & $\begin{array}{l}\text { Not controlled for other interventions } \\
\text { ? Definition of ARDS }\end{array}$ \\
\hline Michelet et al. [28] & $\begin{array}{l}\text { Mortality } \\
\text { Pneumonia } \\
\text { Duration MV }\end{array}$ & $\begin{array}{l}\text { 30/88 (34\%) MV } \\
6 / 30(20 \%) \text { pneumonia } \\
5 / 30(17 \%) \text { septic shock } \\
\text { No deaths } \\
3 \pm 2 \text { days }\end{array}$ & Not controlled for other interventions \\
\hline Cerland et al. [39] & $\begin{array}{l}\text { Mortality } \\
\text { Pneumonia } \\
\text { ARDS } \\
\text { ECLS }\end{array}$ & $\begin{array}{l}\text { 64/144 (44\%) MV } \\
\text { 35/144 (24\%) pneumonia } \\
\text { 23/144 (16\%) ARDS } \\
\text { 45/144 (31\%) died } \\
\text { 2/64 (3\%) ECLS }\end{array}$ & $\begin{array}{l}\text { Not controlled for other interventions; outcomes not } \\
\text { group specific }\end{array}$ \\
\hline Michelet et al. [29] & $\begin{array}{l}\text { Mortality } \\
\text { Duration MV }\end{array}$ & $\begin{array}{l}\text { 40/76 (53) MV } \\
15 / 76(20 \%) \text { died } \\
8 \text { ( } \pm 16) \text { days }\end{array}$ & Unclear ventilatory modes and outcomes \\
\hline
\end{tabular}

MV, mechanical ventilation; ARDS, Acute Respiratory Distress Syndrome; ECLS, extra-corporeal life support

\section{Other treatment modalities}

One paper reports the use of bronchodilators (aminophylline) in 22/98 patients with a minimum of one and potentially two deaths, as well as the use of plasma in $12 / 98$ patients with a minimum of one and potentially three deaths [41]. Mortality results were extrapolated from grouped data.

\section{Discussion}

The key finding from this review is the lack of evidence informing the treatment of the lung injuries associated with drowning. There was a single retrospective comparison of treatments [28]. This is in stark contrast to eight included studies $[10,15,16,18,29,36,37,41]$ that compare outcomes of drownings between fresh and salt water. 
Table 3 Outcomes of non-invasive ventilation in drowning

\begin{tabular}{|c|c|c|c|}
\hline Study & Outcome measured & Outcome & Confounders \\
\hline Modell et al. [16] & Mortality & $\begin{array}{l}24 \text { spontaneously ventilating patients received } \\
\text { intermittent positive end expiratory pressure } \\
10 / 90(11 \%) \text { died }\end{array}$ & $\begin{array}{l}\text { Not controlled for other interventions; outcomes not } \\
\text { group specific }\end{array}$ \\
\hline Dick et al. [40] & Mortality & $\begin{array}{l}\text { 11/18 (61\%) NIV, } \\
2 / 18(11 \%) \text { died }\end{array}$ & $\begin{array}{l}\text { Not controlled for other interventions; outcomes not } \\
\text { group specific }\end{array}$ \\
\hline Cerland et al. [39] & $\begin{array}{l}\text { Mortality } \\
\text { Pneumonia } \\
\text { ARDS }\end{array}$ & $\begin{array}{l}\text { 28/144 (19\%) NIV } \\
\text { 35/144 (24\%) pneumonia } \\
\text { 23/144 (16\%) ARDS } \\
\text { 45/144 (31\%) died }\end{array}$ & $\begin{array}{l}\text { Not controlled for other interventions; outcomes not } \\
\text { group specific }\end{array}$ \\
\hline Michelet et al. [28] & $\begin{array}{l}\text { Mortality } \\
\text { Conversion to MV } \\
\text { Pneumonia } \\
\text { Duration NIV }\end{array}$ & $\begin{array}{l}48 / 88(55 \%) \text { NIV } \\
4 / 48(8 \%) \text { escalated to MV } \\
1 / 48(2 \%) \text { pneumonia } \\
1.4 \pm 0.7 \text { days }\end{array}$ & Not controlled for other interventions \\
\hline Michelet et al. [29] & $\begin{array}{l}\text { Mortality } \\
\text { Pulmonary Complications } \\
\text { Duration NIV }\end{array}$ & $\begin{array}{l}\text { 13/76 (17\%) NIV } \\
4 / 76(5 \%) \text { pneumonia } \\
15 / 76(20 \%) \text { died } \\
1.3 \pm 5 \text { days }\end{array}$ & Outcomes not group specific \\
\hline
\end{tabular}

NIV, non-invasive ventilation; ARDS, Acute Respiratory Distress Syndrome; MV, mechanical ventilation

In 1973, it was reported that the lung injury associated with drowning was rapidly reversible with the application of positive pressure mechanical ventilation [56]. Following this, several studies reported a high incidence of barotrauma when treating drowning with MV [15, 17, 19]. Subsequently, the similarities between the lung injury in drowning and ARDS have been established [6]. Randomised trials have established the safety and efficacy of LPV in ARDS [57], and it has been adopted as best practice in the management of the lung injury associated with drowning $[7,11]$. This may explain the decrease in reported barotrauma associated with MV in recent studies; however, it was not documented as a measured outcome [28, 29, 39].

The use of NIV in drowning was first reported in 1982 [40]; however, it has only been recently that any substantive evidence has been presented regarding the efficacy of NIV in the drowning patient [28, 29, 39]. When compared with MV for the treatment of drowning patients, NIV is similarly effective as MV in reversing hypoxia but is required for a significantly shorter duration $(1.4 \pm 2.4$ vs $6 \pm 12$ days, $P=0.004)[28,29]$. This has to be interpreted with caution given different indications for both treatments $[15,32,39,52,54]$, but a recent study also established the efficacy and safety of NIV in mild to moderate ARDS [58].

Oxygen therapy using HFNP has been adopted widely from the treatment of bronchiolitis to many other causes of respiratory insufficiency in children and adult patients [59]. There is a single report of its use in drowning [53]. There is, however, such a lack of evidence that we can only recommend clinical judgement be applied when deciding on therapeutic strategies when supplemental oxygen alone is insufficient.

It was surprising that the majority of published studies regarding the treatment of drowning are on the use of ECLS. The Extracorporeal Life Support Organization international database has over 400 centres contributing data [21]. Despite this, there were only 247 drowning patients included over a 30-year period. Clearly, the use of ECLS in drowning patients is not a common occurrence. However, the survival rates in patients with cardiac arrest (57\% with ROSC, 23\% with ECLS) compare favourably to published survival rates post-drowning associated cardiac arrest in Germany (18\%) [60], Sweden (14\%) [61] and France (9\%) [62]. There were one meta-analysis and one systematic review examining ECLS in the treatment of drowning and hypothermia that were not included in this paper $[63,64]$. Both studies grouped drowning and avalanche patients in 'asphyxial' groups, and the drowning outcomes could not be separated. However, the outcomes for this group of patients were much worse when compared with isolated hypothermic cardiac arrest with $23.4 \%$ vs $67.7 \%$ survival [63] and an odds ratio for survival of $0.19(0.11-0.35)$ [64].

No study reported on the efficacy of any of the adjuvant therapies in isolation. Added to this was the confounder that all treatments were administered at the clinicians' discretion and, almost certainly, there was significant treatment bias with sicker patients more likely to receive $\mathrm{MV}$ and adjuvant therapies, such as steroids and antibiotics. van Berkel et al. (1996) did conduct a regression analysis attempting to control for confounding variables and concluded that there was no 
Table 4 Outcomes of antibiotic prophylaxis

\begin{tabular}{|c|c|c|c|}
\hline Study & Outcome measured & Outcome & Confounders \\
\hline Modell et al. [16] & Mortality & $\begin{array}{l}\text { 54/90 (60\%) ABP, } 7 / 54(13 \%) \text { died } \\
36 / 90(40 \%) \text { no ABP, } 2 / 36(6 \%) \text { died }\end{array}$ & Not controlled for other interventions \\
\hline Orlowski [18] & Unclear & $\begin{array}{l}\text { "The use of corticosteroids, antibiotic prophylaxis } \\
\text { and diuretics did not improve prognosis" (data } \\
\text { not shown) }\end{array}$ & $\begin{array}{l}\text { Not controlled for other interventions; outcomes } \\
\text { not group specific }\end{array}$ \\
\hline Corbin [41] & Mortality & $\begin{array}{l}79 \text { patients treated. Minimum of one death, poten- } \\
\text { tially three }\end{array}$ & $\begin{array}{l}\text { Not controlled for other interventions; outcomes } \\
\text { not group specific }\end{array}$ \\
\hline Dick et al. [40] & Mortality & $\begin{array}{l}\text { 16/18 (89\%) ABP } \\
2 / 18(11 \%) \text { died }\end{array}$ & $\begin{array}{l}\text { Not controlled for other interventions; outcomes } \\
\text { not group specific }\end{array}$ \\
\hline Oakes et al. [17] & $\begin{array}{l}\text { Mortality } \\
\text { Pneumonia }\end{array}$ & $\begin{array}{l}31 / 40(78 \%) \text { ABP } \\
16 / 40(40 \%) \text { pneumonia } \\
10 / 40(25 \%) \text { died }\end{array}$ & $\begin{array}{l}\text { Not controlled for other interventions; outcomes } \\
\text { not group specific }\end{array}$ \\
\hline Simcock [33] & $\begin{array}{l}\text { Mortality } \\
\text { Pneumonia } \\
\text { ARDS }\end{array}$ & $\begin{array}{l}\text { 68/121 (56\%) ABP } \\
\text { 12/68 (18\%) died ( } 1 \text { from pneumonia, } 1 \text { from ARDS) } \\
53 / 121(44 \%) \text { no ABP, } 0 \text { died }\end{array}$ & $\begin{array}{l}\text { Not controlled for other interventions Treatment } \\
\text { determined by severity of illness }\end{array}$ \\
\hline van Berkel et al. [36] & $\begin{array}{l}\text { Mortality } \\
\text { Pneumonia } \\
\text { Duration of MV }\end{array}$ & $\begin{array}{l}\text { 45/102 (44\%) ABP } \\
\text { 15/102(15\%) pneumonia } \\
\text { 7/102 (7\%) died, } 3 \text { from pneumonia } \\
\text { No effect of ABP on duration of MV, ICU LOS or } \\
\text { hospital LOS (data not shown) }\end{array}$ & $\begin{array}{l}\text { Not controlled for other interventions; outcomes } \\
\text { not group specific }\end{array}$ \\
\hline Lee $[10]$ & Pneumonia & $\begin{array}{l}\text { 16/17 (94.1\%) ABP } \\
0 / 17(0.0 \%) \text { pneumonia }\end{array}$ & Not controlled for other interventions \\
\hline Saidel-Odes et al. [52] & $\begin{array}{l}\text { Mortality } \\
\text { Pneumonia } \\
\text { ARDS }\end{array}$ & $\begin{array}{l}\text { 42/69 (61\%) ABP } \\
\text { 26/69 (38\%) pneumonia } \\
\text { 3/69 (4\%) ARDS } \\
\text { No deaths }\end{array}$ & $\begin{array}{l}\text { Not controlled for other interventions; outcomes } \\
\text { not group specific }\end{array}$ \\
\hline Gregorakos et al. [9] & $\begin{array}{l}\text { Pneumonia } \\
\text { ARDS }\end{array}$ & $\begin{array}{l}\text { 43/43 ABP } \\
4 / 43(9 \%) \text { pneumonia } \\
1 / 43(2 \%) \text { died from pneumonia }\end{array}$ & Not controlled for other interventions \\
\hline Ballesteros et al. [38] & $\begin{array}{l}\text { Mortality } \\
\text { Septic outcomes }\end{array}$ & $\begin{array}{l}27 / 43(62.8 \%) \text { ABP } \\
15 / 43(35 \%) \text { died } \\
1 / 43(2 \%) \text { died from pneumonia } \\
\text { No effect of ABP on outcomes (data not shown) }\end{array}$ & $\begin{array}{l}\text { Not controlled for other interventions; outcomes } \\
\text { not group specific }\end{array}$ \\
\hline Kim [47] & Mortality & $\begin{array}{l}\text { 9/9 (100\%) ABP } \\
2 / 9(22.2 \%) \text { died }\end{array}$ & All patients received ECLS \\
\hline Cerland et al. [39] & $\begin{array}{l}\text { Mortality } \\
\text { Pneumonia } \\
\text { ARDS }\end{array}$ & $\begin{array}{l}\text { 85/144 (59\%) ABP } \\
\text { 35/144 (24\%) pneumonia } \\
\text { 23/144 (16\%) ARDS } \\
\text { 45/144 (31\%) died }\end{array}$ & $\begin{array}{l}\text { Not controlled for other interventions; outcomes } \\
\text { not group specific }\end{array}$ \\
\hline Robert et al. [30] & $\begin{array}{l}\text { Mortality } \\
\text { Pneumonia } \\
\text { ARDS }\end{array}$ & $\begin{array}{l}\text { 44/74 (59\%) ABP } \\
\text { 36/74 (49\%) pneumonia } \\
\text { 25/74 (34\%) ARDS } \\
\text { 19/74 (26\%) died }\end{array}$ & Outcomes not group specific \\
\hline
\end{tabular}

ABP, antibiotic prophylaxis; ARDS, Acute Respiratory Distress Syndrome; ECLS, extracorporeal life support

benefit from any of the adjuvant therapies with regards to duration of MV, hospital or ICU LOS [36]. They also concluded that MV was a risk factor for developing pneumonia post-drowning without presenting the data or outlining the variables included in the analysis [36]. Clinical trials in ARDS have established a lack of efficacy for steroids [65] and surfactant [66, 67]. The evidence for or against diuretic therapy in ARDS is less clear $[68,69]$. The lack of evidence in drowning prevents any recommendations.

\section{Implications for future research}

While drowning is a common cause of death worldwide [1], it is neither a common cause of ED presentations [70, 71] nor hospital admissions [72]. This may explain the apparent lack of evidence regarding its management. The lack of comparative studies and scarcity of multi-centre collaborations are of concern and must be addressed urgently. This is especially so given the demonstrated value of the Extracorporeal Life Support Organization's international registry in informing the use of ECMO in drowning patients. 


\section{Limitations}

This structured evidence-based review was aimed at establishing the primary evidence behind the treatment of the lung injuries associated with drowning. The World Health Organisation published a uniform definition of drowning and its outcomes in 2005 [4]. More than half of the studies included in this review were published after 2005. Unfortunately, only four of them use the correct definition [28-30, 50]. Without a consistent definition of a drowning patient, it is hard to integrate the published evidence.

The search strategy excluded any papers written in languages other than English. Given the very low quality of evidence, one or two high-quality non-English language papers may have changed the findings of the review.

\section{Conclusions}

There is a dire lack of evidence informing the management of the drowning patient. This makes any recommendations regarding best practice impossible other than to follow local guidelines and clinical judgement. There is an urgent need for high-quality research on the treatment of drowning. Duration of immersion is a critical factor in patient prognosis [8], and as such, prevention is currently the most effective strategy in reducing drowning mortality.

\begin{abstract}
Abbreviations
ABP: Antibiotic prophylaxis; ARDS: Acute respiratory distress syndrome; CPC: Cerebral performance category; ECLS: Extra-corporeal life support; ECPR: ECLSassisted cardio-pulmonary resuscitation; EMS: Emergency medical services; GNO: Good neurological outcome; GOSE: Glasgow outcome scale extended; GRADE: Grading of recommendations assessment, development and evaluation methodology; HFNP: High flow nasal prongs; ICU: Intensive care unit; LOS: Length of stay; LPV: Lung protective ventilation; MV: Mechanical ventilation; NIV: Non-invasive ventilation; PCPC: Paediatric cerebral performance category; PRISMA: Preferred reporting items for systematic reviews and meta-analyses; ROSC: Return of spontaneous circulation; USFD: Utstein style for drowning.
\end{abstract}

\section{Supplementary Information}

The online version contains supplementary material available at https://doi. org/10.1186/s13054-021-03687-2.

Additional file 1. Medline search strategy.

Additional file 2. GRADE evidence summary of included studies.

Additional file 3. Summary Table of included studies.

\section{Acknowledgements}

Not applicable.

\section{Authors' contributions}

OT, KR, SD, PL, RF participated in study concept and design, OT and KR conducted the acquisition of the data, OT and KR conducted the analysis and interpretation of the data, OT drafted the manuscript, OT, KR, SD, PL, RF conducted critical revision of the manuscript and OT and KR participated in acquisition of funding. All authors read and approved the final manuscript.

\section{Funding}

This study was supported by an Australian Government Research Training Program Scholarship. Two authors (OT and KR) have also been supported by the Doctoral Cohort programme Division of Tropical Health and Medicine, James Cook University and the Emergency Department, Sunshine Coast University Hospital.

\section{Availability of data and materials}

All data generated or analysed in this study are included in this published article (and its Additional files).

\section{Declarations}

Ethical approval and consent to participate

Not applicable.

\section{Consent for publication}

Not applicable.

\section{Competing interests}

The authors declare that they have no competing interests.

\section{Author details}

${ }^{1}$ College of Public Health, Medical and Veterinary Sciences, James Cook University,Townsville, QLD, Australia. ${ }^{2}$ Department of Emergency Medicine, Sunshine Coast Hospital and Health Service,Sunshine Coast, QLD, Australia. ${ }^{3}$ School of Medicine, National University of Ireland Galway, Galway, Ireland. ${ }^{4}$ Royal Life Saving - Australia, National Office, Broadway, Sydney, Australia.

Received: 19 May 2021 Accepted: 6 July 2021

Published online: 19 July 2021

\section{References}

1. World Health Organization. Global report on drowning: preventing a leading killer. Geneva: World Health Organization; 2014

2. Franklin RC, Peden AE, Hamilton EB, et al. The burden of unintentional drowning: global, regional and national estimates of mortality from the Global Burden of Disease 2017 Study. Inj Prev. 2020; 26(Suppl 2): i83-i95.

3. Howard B. The direct method of artificial respiration for the treatment of apnoea from drowning, anaesthetics, still-birth, etc.; with a typical case of each, treated by the author, in which Oher methods were not immediately practicable. Lancet. 1878;111:748-52.

4. Van Beeck EF, Branche CM, Szpilman D, Modell JH, Bierens JJLM. A new definition of drowning: towards documentation and prevention of a global public health problem. Bull World Health Organ. 2005;83:853-6.

5. Idris AH, Berg RA, Bierens J, et al. Recommended guidelines for uniform reporting of data from drowning: the "Utstein style." Resuscitation. 2003;59:45-57.

6. Bierens JJLM, Lunetta P, Tipton M, Warner DS. Physiology of drowning: a review. Physiology. 2016;31:147-66.

7. Szpilman D, Bierens JJ, Handley AJ, Orlowski JP. Drowning. N Engl J Med. 2012;366:2102-10.

8. Quan L, Bierens J, Lis R, Rowhani-Rahbar A, Morley P, Perkins GD. Predicting outcome of drowning at the scene: a systematic review and metaanalyses. Resuscitation. 2016;104:63-75.

9. Gregorakos L, Markou N, Psalida V, et al. Near-drowning: clinical course of lung injury in adults. Lung. 2009;187:93-7.

10. Lee $\mathrm{KH}$. A retrospective study of near-drowning victims admitted to the intensive care unit. Ann Acad Med Singap. 1998;27:344-6.

11. Schmidt AC, Sempsrott JR, Hawkins SC, Arastu AS, Cushing TA, Auerbach PS. Wilderness medical society practice guidelines for the prevention and treatment of drowning. Wilderness Environ Med. 2016;27:236-51.

12. Moher D, Liberati A, Tetzlaff J, Altman DG, Group P. Preferred reporting items for systematic reviews and meta-analyses: the PRISMA statement. BMJ 2009;339:b2535. 
13. Guyatt G, Oxman AD, Akl EA, et al. GRADE guidelines: 1. IntroductionGRADE evidence profiles and summary of findings tables. J Clin Epidemiol. 2011;64:383-94.

14. Guyatt GH, Oxman AD, Vist $G$, et al. GRADE guidelines: 4. Rating the quality of evidence-study limitations (risk of bias). J Clin Epidemiol. 2011;64:407-15.

15. Fandel I, Bancalari E. Near-drowning in children: clinical aspects. Pediatrics. 1976;58:573-9.

16. Modell JH, Graves SA, Ketover A. Clinical course of 91 consecutive neardrowning victims. Chest. 1976;70:231-8.

17. Oakes DD, Sherck JP, Maloney JR, Charters IAC. Prognosis and management of victims of near-drowning. J Trauma. 1982;22:544-9.

18. Orlowski JP. Prognostic factors in pediatric cases of drowning and neardrowning. JACEP. 1979;8:176-9.

19. Peterson B. Morbidity of childhood near drowning. Pediatrics. 1977:59:364-70.

20. Bauman BD, Louiselle A, Nygaard RM, et al. Treatment of hypothermic cardiac arrest in the pediatric drowning victim, a case report, and systematic review. Pediatric Emerg Care. 2019.

21. Burke CR, Chan T, Brogan TV, et al. Extracorporeal life support for victims of drowning. Resuscitation. 2016;104:19-23.

22. Saltiel A, Kopf GS, Elefteriades J, et al. Resuscitation of cold water immersion victims with cardiopulmonary bypass. J Crit Care. 1989:4:54-7.

23. Scaife ER, Connors RC, Morris SE, et al. An established extracorporeal membrane oxygenation protocol promotes survival in extreme hypothermia. J Pediatr Surg. 2007:42:2012-6.

24. Skarda D, Barnhart D, Scaife E, Molitor M, Meyers R, Rollins M. Extracorporeal cardiopulmonary resuscitation (EC-CPR) for hypothermic arrest in children: is meaningful survival a reasonable expectation? J Pediatr Surg. 2012:47:2239-43.

25. Steiner RB, Adolph VR, Heaton JF, Bonis SL, Falterman KW, Arensman RM. Pediatric extracorporeal membrane oxygenation in posttraumatic respiratory failure. J Pediatr Surg. 1991;26:1011-4.

26. Watson JA, Englum BR, Kim J, et al. Extracorporeal life support use in pediatric trauma: a review of the National Trauma Data Bank. J Pediatr Surg. 2017;52:136-9.

27. Weber TR, Kountzman B. Extracorporeal membrane oxygenation for nonneonatal pulmonary and multiple-organ failure. J Pediatr Surg. 1998:33:1605-9.

28. Michelet $\mathrm{P}$, Bouzana F, Charmensat $\mathrm{O}$, et al. Acute respiratory failure after drowning: a retrospective multicenter survey. Eur J Emerg Med. 2017;24:295-300.

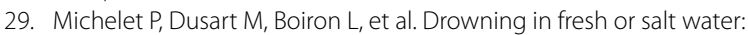
respective influence on respiratory function in a matched cohort study. Eur J Emerg Med. 2019;26:340-4.

30. Robert A, Danin PE, Quintard H, et al. Seawater drowning-associated pneumonia: a 10-year descriptive cohort in intensive care unit. Ann Intensive Care. 2017;7:45.

31. Champigneulle B, Bellenfant-Zegdi F, Follin A, et al. Extracorporeal life support (ECLS) for refractory cardiac arrest after drowning: an 11-year experience. Resuscitation. 2015;88:126-31.

32. Al-Talafieh A, Al-Majali R, Al-Dehayat G. Clinical, laboratory and X-ray findings of drowning and near-drowning in the Gulf of Aqaba. East Mediterr Health J. 1999:5:706-9.

33. Simcock AD. Treatment of near drowning. A review of 130 cases. Anaesthesia. 1986:41:643-8

34. Walpoth BH, Locher T, Leupi F, Schupbach P, Muhlemann W, Althaus U. Accidental deep hypothermia with cardiopulmonary arrest: extracorporeal blood rewarming in 11 patients. Eur I Cardiothorac Surg. 1990;4:390-3.

35. Wanscher M, Agersnap L, Ravn J, et al. Outcome of accidental hypothermia with or without circulatory arrest: experience from the Danish Praesto Fjord boating accident. Resuscitation. 2012;83:1078-84.

36. Van Berkel M, Bierens JJLM, Lie RLK, et al. Pulmonary oedema, pneumonia and mortality in submersion victims a retrospective study in 125 patients. Intensive Care Med. 1996;22:101-7.

37. Lee HK, Kim HS, Ha SO, et al. Clinical outcomes of extracorporeal membrane oxygenation in acute traumatic lung injury: a retrospective study. Scand J Trauma Resuscitation Emerg Med 2020;28:41.
38. Ballesteros MÁ, Gutiérrez-Cuadra M, MuÑoz P, MiÑambres E. Prognostic factors and outcome after drowning in an adult population. Acta Anaesthesiol Scand. 2009;53:935-40.

39. Cerland L, Mégarbane B, Kallel H, Brouste Y, Mehdaoui H, Resiere D. Incidence and consequences of near-drowning-related pneumonia-a descriptive series from Martinique, French West Indies. Int J Environ Res Public Health 2017;14.

40. Dick AE, Potgieter PD. Secondary drowning in the Cape Peninsula. S Afr Med J. 1982:62:803-6.

41. Corbin DO, Fraser HS. A review of 98 cases of near-drowning at the Queen Elizabeth Hospital. Barbados West Indian Med J. 1981;30:22-9.

42. Brunette DD, Mcaney K. Hypothermic cardiac arrest: an 11 year review of ED management and outcome. Am J Emerg Med. 2000;18:418-22.

43. Coskun KO, Popov AF, Schmitto JD, et al. Extracorporeal circulation for rewarming in drowning and near-drowning pediatric patients. Artif Organs. 2010;34:1026-30

44. Eich C, Brauer A, Timmermann A, et al. Outcome of 12 drowned children with attempted resuscitation on cardiopulmonary bypass: an analysis of variables based on the "Utstein Style for Drowning." Resuscitation. 2007;75:42-52.

45. Farstad M, Andersen KS, Koller ME, Grong K, Segadal L, Husby P. Rewarming from accidental hypothermia by extracorporeal circulation. A retrospective study. Eur J Cardio-Thoracic Surg. 2001;20:58-64.

46. Khorsandi M, Dougherty S, Young N, et al. Extracorporeal life support for refractory cardiac arrest from accidental hypothermia: a 10-year experience in Edinburgh. J Emerg Med. 2017;52:160-8.

47. Kim KI, Lee WY, Kim HS, Jeong JH, Ko HH. Extracorporeal membrane oxygenation in near-drowning patients with cardiac or pulmonary failure. Scand J Trauma Resuscitation Emerg Med. 2014;22:77.

48. Mair P, Kornberger E, Furtwaengler W, Balogh D, Antretter H. Prognostic markers in patients with severe accidental hypothermia and cardiocirculatory arrest. Resuscitation. 1994;27:47-54.

49. Suominen PK, Vallila NH, Hartikainen LM, Sairanen HI, Korpela RE. Outcome of drowned hypothermic children with cardiac arrest treated with cardiopulmonary bypass. Acta Anaesthesiol Scand. 2010;54:1276-81.

50. Weuster M, Haneya A, Panholzer B, et al. The use of extracorporeal membrane oxygenation systems in severe accidental hypothermia after drowning: a centre experience. ASAIO J. 2016:62:157-62.

51. Wollenek G, Honarwar N, Golej J, Marx M. Cold water submersion and cardiac arrest in treatment of severe hypothermia with cardiopulmonary bypass. Resuscitation. 2002;52:255-63.

52. Saidel-Odes $L R$, Almog $Y$. Near-drowning in the dead sea: a retrospective observational analysis of 69 patients. Isr Med Assoc J. 2003;5:856-8.

53. Kim JH, Sun KH, Park YJ. The utility of non-invasive nasal positive pressure ventilation for acute respiratory distress syndrome in near drowning patients. J Trauma Inj. 2019;32:136-42.

54. Kotsiou O, Pasparaki E, Bibaki E, et al. Drowning and near drowning victims in Chania area. Pneumon. 2014;27:231-5.

55. Acute Respiratory Distress Syndrome N, Brower RG, Matthay MA, et al. Ventilation with lower tidal volumes as compared with traditional tidal volumes for acute lung injury and the acute respiratory distress syndrome. N Engl J Med 2000;342:1301-8.

56. Rutledge RR, Flor RJ. Use of mechanical ventilation with positive endexpiratory pressure in treatment of near-drowning. Anesthesiology. 1973;38:194-6.

57. Acute Respiratory Distress Syndrome Network, Brower RG, Matthay MA, et al. Ventilation with lower tidal volumes as compared with traditional tidal volumes for acute lung injury and the acute respiratory distress syndrome. N Engl J Med 2000;342:1301-8.

58. Khemani RG, Smith L, Lopez-Fernandez YM, et al. Paediatric acute respiratory distress syndrome incidence and epidemiology (PARDIE): an international, observational study. Lancet Respir Med. 2019;7:115-28.

59. Zhao H, Wang H, Sun F, Lyu S, An Y. High-flow nasal cannula oxygen therapy is superior to conventional oxygen therapy but not to noninvasive mechanical ventilation on intubation rate: a systematic review and meta-analysis. Crit Care. 2017;21:184.

60. Gässler H, Fischer M, Wnent J, Seewald S, Helm M. Outcome after prehospital cardiac arrest in accordance with underlying cause. Resuscitation. 2019;138:36-41. 
61. Claesson A, Djarv T, Nordberg P, et al. Medical versus non medical etiology in out-of-hospital cardiac arrest-changes in outcome in relation to the revised Utstein template. Resuscitation. 2017;110:48-55.

62. Hubert $\mathrm{H}$, Escutnaire J, Michelet $\mathrm{P}$, et al. Can we identify termination of resuscitation criteria in cardiac arrest due to drowning: results from the French national out-of-hospital cardiac arrest registry. J Eval Clin Pract. 2016;22:924-31.

63. Dunne B, Christou E, Duff O, Merry C. Extracorporeal-assisted rewarming in the management of accidental deep hypothermic cardiac arrest: a systematic review of the literature. Heart Lung Circ. 2014;23:1029-35.

64. Saczkowski RS, Brown DJA, Abu-Laban RB, Fradet G, Schulze CJ, Kuzak ND. Prediction and risk stratification of survival in accidental hypothermia requiring extracorporeal life support: an individual patient data metaanalysis. Resuscitation. 2018;127:51-7.

65. Steinberg KP, Hudson LD, Goodman RB, et al. Efficacy and safety of corticosteroids for persistent acute respiratory distress syndrome. N Engl J Med. 2006;354:1671-84.

66. Willson DF, Thomas NJ, Markovitz BP, et al. Effect of exogenous surfactant (calfactant) in pediatric acute lung injury: a randomized controlled trial. JAMA. 2005:293:470-6.

67. Willson DF, Truwit JD, Conaway MR, Traul CS, Egan EE. The adult calfactant in acute respiratory distress syndrome trial. Chest. 2015;148:356-64.
68. National Heart Lung and Blood Institute Acute Respiratory Distress Syndrome Clinical Trials Network, Wiedemann HP, Wheeler AP, et al. Comparison of two fluid-management strategies in acute lung injury. N Engl J Med. 2006;354:2564-75.

69. Semler MW, Wheeler AP, Thompson BT, et al. Impact of initial central venous pressure on outcomes of conservative versus liberal fluid management in acute respiratory distress syndrome. Crit Care Med. 2016;44:782-9.

70. El Sibai R, Bachir R, El Sayed M. Submersion injuries in the United States: patients characteristics and predictors of mortality and morbidity. Injury. 2018:49:543-8

71. Wallis BA, Watt K, Franklin RC, Nixon JW, Kimble RM. Drowning mortality and morbidity rates in children and adolescents 0-19yrs: a populationbased study in Queensland, Australia. PLoS ONE. 2015;10:e117948-e.

72. Peden AE, Mahony AJ, Barnsley PD, Scarr J. Understanding the full burden of drowning: A retrospective, cross-sectional analysis of fatal and nonfatal drowning in Australia. BMJ Open 2018;8:e024868.

\section{Publisher's Note}

Springer Nature remains neutral with regard to jurisdictional claims in published maps and institutional affiliations.
Ready to submit your research? Choose BMC and benefit from:

- fast, convenient online submission

- thorough peer review by experienced researchers in your field

- rapid publication on acceptance

- support for research data, including large and complex data types

- gold Open Access which fosters wider collaboration and increased citations

- maximum visibility for your research: over $100 \mathrm{M}$ website views per year

At BMC, research is always in progress.

Learn more biomedcentral.com/submissions 